\title{
Changes in bacterial microflora in young carrier pigeons during the race season
}

\begin{abstract}
Pigeons are during the race season exposed to various adverse effects. Increased stress during the race is an important factor that significantly affects their health and composition of bacterial microflora. The aim of this study was to observe the changes in bacterial microflora and health status of 60 young carrier pigeons in age $6-7$ months during the race period. At the beginning and at the end of the race season were taken the samples of swabs from cloaca, oropharynx and infraorbital sinuses of the young carrier pigeons. The predominant gram-positive bacterial strains isolated in the samples from cloaca were Ent. faecalis, Ent. faecium, E. columbae and Str. faecalis in both collections of the pigeon gastrointestinal tract. At the beginning race season in swabs from oropharynx were most isolated strains Ent. gallinarum, E. coli and Ent. faecalis. At the end of race season were isolated from oropharyngeal swabs Ent. columbae, Ent. faecalis and coagulase negative staphylococci (S. xylosus, S. schleiferi and S. epidermidis), which also act as an opportune pathogen for immuno depression. Comparing the most common diseases of pigeons, we found an increased incidence of coccidiosis (40.4\%), trichomoniasis (17.3\%), endoparasitosis $(11.5 \%)$ and respiratory syndrome $(7.7 \%)$ after the race season. The enterococcal and streptococcal intestinal flora of young pigeons during the race season is dominated and composed of mainly host specific bacteria by Ent. faecalis, Ent. faecium, Ent. columbae, Str. gallolyticus and Str. faecalis. The increased incidence of diseases in pigeons during the race season may affect the presence of commensal bacteria especially coagulase negative and positive staphylococci.
\end{abstract}

Keywords: carrier pigeons, race season, intestinal flora, enterococcus spp, staphylococcus spp
Volume 2 Issue 2 - 2017

\author{
František Zigo,' Ladislav Takáč,' Martina \\ Zigová, ${ }^{2}$ Jana Takáčová! \\ 'Department of Animal husbandry, University of Veterinary \\ Medicine and Pharmacy, Slovakia \\ ${ }^{2}$ Faculty of Medicine, Department of Pharmacology, ${ }^{2}$ University \\ of Pavol Jozef Šafárik in Košice, Slovakia
}

\begin{abstract}
Correspondence: František Zigo, University of Veterinary Medicine and Pharmacy, Department of Animal husbandry, Košice, Komenského 73, 040 0I, Slovakia, Tel +42I-908-689-722, Email frantisek.zigo@uvlf.sk
\end{abstract}

Received: May 18, 2017| Published: June 20, 2017

\section{Introduction}

One of the fastest developing spheres of animal breeding is keeping domestic pigeons. The current use of pigeons for sport activities with rising demands on the fly speed, good form and magnificent orientation skills also increases demands for correct care, zoo-hygiene conditions and balanced nutrition. ${ }^{1}$ The most vulnerable to infections are carrier and sporting pigeons, as they perform a large number of flights in the so-called racing season. This leads to substantial exhaustion of birds and, consequently, increases their susceptibility to various diseases, including infections with coccidiosis, salmonellosis, paramyxoviruses, cirkoviruses, trichomoniasis and respiratory infections. ${ }^{2,3}$ Particularly young pigeons are exposed to increased physical demands during the race season, which may have a negative impact on the change in the composition of the bacterial microflora. ${ }^{1,4}$ About the composition of micrococcal flora in the intestines and faeces of pigeons is little known. The intestinal microflora of gallinaceous birds such as chickens and turkey is probably different from that of pigeons. Pigeons possess only rudimentary developed caeca, the part of the intestines, which harbours the most abundant and diversified microflora. It has been suggested that birds such as passerines, which do not possess developed caeca, do not have a permanent gut flora. ${ }^{4,5}$ The aim of this study was to observe the changes in bacterial microflora and health status in 60 young carrier pigeons during the race period.

\section{Material and methods}

\section{Animals and samples}

The study included young pigeons in age 6-7 months, which for two months completed seven races at a distance of $100-300 \mathrm{~km}$. Clinical examination was performed according to Scullion FT, Scullion. ${ }^{6}$ Faecal samples, swabs of the cloaca, oropharynx and infraorbital sinuses were collected from 60 young carrier pigeons at the beginning of race season originated from holding on east of Slovakia. On the end of race season were taken samples of swabs from 52 pigeons because 8 pieces were lost during the races.

\section{Laboratory analysis}

The floatation technique was used for detecting coccidiosis and endoparasitosis from faecal samples according to Dranzoa et al. ${ }^{7}$ Determination of trichomoniasis from swabs of the oropharynx and crop as well as detection of ectoparasitosis was performed according to Stenzel T, Koncicki. ${ }^{8}$ Each sample was cultivated on conventional nonselective media (blood agar) and selective media (Endo agar) under aerobic conditions. Fermentative gram-negative rods of the family Enterobacteriaceae were determined by standard biochemical procedures using Enterotest 24 and Enterotest 16 (Lachema, Czech Republic). Staphylococci and Streptococci were identified according to their characteristics growth on blood agar (Oxoid) and by standard biochemical procedures using Staphytest and Streptotest (Lachema). According to the criteria of Facklam and Collins ${ }^{9}$ were identified enterococci and by their biochemical activities using En-coccus test (Lachema).

\section{Statistical analysis}

Statistical analysis was performed using software Chi quadrate test for comparison of the most common diseases of pigeons before and after race season. A paired t-test was used to evaluate whether 
the differences between isolated strains from swabs of the cloaca, oropharynx and infraorbital sinuses at the beginning and at the end of race season are significant or not. Differences were considered as significant at the level of 0.05 or less.

\section{Results and discussion}

Microbial flora of the pigeon gastrointestinal tract is characterized by occurrence of $E$. coli and enterococci. Escherichia coli are usually commensal, but can also act as an opportune pathogen. Several factors are needed for $E$. coli to cause disease in pigeons, such as stress or adenoviralor herpesviral infection. ${ }^{4,10}$ In our study the enterococcal and streptococcal intestinal flora of pigeons was dominated. The predominat gram-positive bacterial strains of both collections from swabs of cloaca are Ent. faecalis, Ent. faecium, Ent. columbae, Str. faecalis and Str. gallolyticus (Table 1). Among the most frequent enterococcal species isolated from feral pigeons in $\mathrm{Brno}^{11}$ were Ent. faecalis and Ent. faecium, while Ent. columbae occurred only in a minority of the samples. Enterococci of feral pigeons were also studied in Belgium, ${ }^{5}$ where Ent. columbae was the most frequent gram-positive facultative anaerobic component of the pigeon intestinal flora.

Table I Young pigeons-before race season

\begin{tabular}{|c|c|c|c|c|c|c|c|c|}
\hline \multirow{2}{*}{ Isolated Bacteria } & \multicolumn{2}{|c|}{ Pigeons (60) } & \multicolumn{2}{|c|}{ Cloaca } & \multicolumn{2}{|c|}{ Oropharynx } & \multicolumn{2}{|c|}{ Infraorbital Sinuses } \\
\hline & $\mathrm{n}$ & $\%$ & $\mathrm{n}$ & $\%$ & $\mathrm{n}$ & $\%$ & $\mathrm{~N}$ & $\%$ \\
\hline E. coli & 56 & 93.3 & 49 & 81.6 & 5 & 8.3 & 2 & 3.3 \\
\hline Ent. faecalis & 39 & 65.0 & 30 & 50.0 & 5 & 8.3 & 4 & 6.6 \\
\hline Ent. columbae & 35 & 58.3 & 29 & 48.3 & 4 & 6.6 & 2 & 3.3 \\
\hline Ent. faecium & 29 & 48.3 & 27 & 45.0 & 2 & 3.3 & - & - \\
\hline Ent. gallinarum & 22 & 36.6 & 10 & 16.6 & 8 & 13.3 & 4 & 6.6 \\
\hline Str. faecalis & 9 & 15.0 & 7 & 11.6 & 2 & 3.3 & - & - \\
\hline S. intermedius' & 8 & 13.3 & 1 & 1.6 & 4 & 6.6 & 3 & 5.0 \\
\hline Str. gallolyticus & 4 & 6.6 & 3 & 5.0 & I & 1.6 & - & - \\
\hline Ent. mundtii & 4 & 6.6 & 3 & 5.0 & I & 1.6 & - & - \\
\hline S. epidermidis ${ }^{2}$ & 4 & 6.6 & - & - & 3 & 5.0 & 1 & 1.6 \\
\hline S. schleiferi ${ }^{2}$ & 4 & 6.6 & - & - & 2 & 3.3 & - & - \\
\hline
\end{tabular}

Legend: n: Number of isolated strains from total 60 investigated pigeons, Coagulase positive staphylococci' - Staphylococcus intermedius, Coagulase negative staphylococci ${ }^{2}$-Staphylococcus epidermidis, Staphylococcus schleiferi

The presence of Ent. columbae and Str. gallolyticus in the pigeon intestinal tract was to confirmed by Devriese et al. ${ }^{12,13}$ Bacteria Str. gallolyticus is an opportunistic pigeon pathogen, which was formerly indiscernible from S. bovis. ${ }^{10}$ Bacteria Ent. cecorum is associated with a wide variety of animal species. ${ }^{14}$ After race season in monitored holding from cloacal swabs were dominated enterococcal strains by Ent. faecalis, Ent. Columbae, Ent. Faecium, Ent. Gallinarum and Ent. Cecorum. Important part of isolated bacteria from cloacal swabs was E. coli and Str. gallolyticus. The most frequently bacteria isolated from oropharyngeal swabs of both collections were E. coli, Ent. faecalis, Ent. columbae and Ent. faecium. In an increased number $(\mathrm{P}<0.05)$ were isolated coagulase negative ( $S$. epidermidis, S. schleiferi, $S$. xylosus) and positive (S. aureus, S. intermedius) staphylococci after race season from oropharynx and infraorbital sinuses swabs, which also act as an opportune pathogen for immuno depression (Table 2). The incidence of diseases in pigeons during the racing season may affect the presence of bacterial microflora. ${ }^{15}$

Table 2 Young pigeons - after race season

\begin{tabular}{lllllllll}
\hline \multirow{2}{*}{ Isolated Bacteria } & \multicolumn{3}{c}{ Pigeons (52) } & \multicolumn{2}{c}{ Cloca } & \multicolumn{2}{c}{ Oropharynx } & \multicolumn{2}{c}{ Infraorbital Sinuses } \\
\cline { 2 - 9 } & $\mathrm{n}$ & $\%$ & $\mathrm{n}$ & $\%$ & $\mathrm{~N}$ & $\%$ & $\mathrm{n}$ & $\%$ \\
\hline Ent. faecalis & 40 & 76.9 & 32 & 61.5 & 5 & 9.6 & 3 & 5.7 \\
E. coli & 34 & 65.3 & 31 & 59.6 & 2 & 3.8 & $\mathrm{I}$ & 1.9 \\
Ent. columbae & 30 & 57.6 & 21 & 40.3 & 6 & 11.5 & 3 & 5.7 \\
Ent. faecium & 21 & 40.3 & 16 & 30.7 & 4 & 7.6 & $\mathrm{I}$ & 1.9 \\
Str. faecalis & 21 & 40.3 & 18 & 34.6 & $\mathrm{I}$ & 1.9 & 2 & 3.8 \\
Str. gallolyticus & 14 & 26.9 & 6 & 11.5 & 5 & 9.6 & 3 & 5.7 \\
Ent. gallinarum & $\mathrm{II}$ & 21.1 & 7 & 13.4 & 3 & 5.7 & $\mathrm{I}$ & 1.9 \\
S. intermedius' & 10 & 19.2 & $\mathrm{I}$ & 1.9 & 8 & 15.3 & $\mathrm{I}$ & 1.9 \\
\hline
\end{tabular}


Table Continued....

\begin{tabular}{|c|c|c|c|c|c|c|c|c|}
\hline \multirow{2}{*}{ Isolated Bacteria } & \multicolumn{2}{|c|}{ Pigeons (52) } & \multicolumn{2}{|c|}{ Cloca } & \multicolumn{2}{|c|}{ Oropharynx } & \multicolumn{2}{|c|}{ Infraorbital Sinuses } \\
\hline & $\mathrm{n}$ & $\%$ & $\mathrm{n}$ & $\%$ & $\mathrm{~N}$ & $\%$ & $\mathrm{n}$ & $\%$ \\
\hline S. $x y l o s u x^{2}$ & 9 & 17.3 & I & 1.9 & 6 & 11.5 & 2 & 3.8 \\
\hline Ent. cecorum & 8 & 15.3 & 7 & 13.4 & I & 1.9 & - & - \\
\hline Bacillus spp. & 8 & 15.3 & - & - & 7 & 13.4 & I & 1.9 \\
\hline Ent. casseliflavus & 7 & 13.4 & 6 & 11.5 & I & 1.9 & - & - \\
\hline S. epidermidis ${ }^{2}$ & 7 & 13.4 & 1 & 1.9 & 4 & 7.6 & 2 & 3.8 \\
\hline Ent. mundtii & 6 & 11,5 & 2 & 3.8 & 4 & 7.6 & - & - \\
\hline S. schleiferi ${ }^{2}$ & 5 & 9,6 & I & 1.9 & 3 & 5.7 & I & 1.9 \\
\hline Str. alactolyticus & 4 & 7.6 & 2 & 3.8 & 2 & 3.8 & - & - \\
\hline Ent. hirae & 3 & 5.7 & 2 & 3.8 & I & 1.9 & - & - \\
\hline Ent. durans & 3 & 5.7 & 2 & 3.8 & I & 1.9 & - & - \\
\hline S. aureus' & 3 & 5.7 & - & - & 3 & 3.8 & - & - \\
\hline S. simulans ${ }^{2}$ & 2 & 3.8 & - & - & I & 1.9 & I & 1.9 \\
\hline S. warneri ${ }^{2}$ & 2 & 3.8 & - & - & 2 & 3.8 & - & - \\
\hline
\end{tabular}

Legend : n: Number of isolated strains from total 52 investigated pigeons, which for two months completed all races, Coagulase positive staphylococci' Staphylococcus aureus, Staphylococcus intermedius, Coagulase negative staphylococci ${ }^{2}$ - Staphylococcus xylosus, Staphylococcus epidermidis, Staphylococcus schleiferi, Staphylococcus simulans, Staphylococcus warneri.

According to Balicka A, Pilarczyk, ${ }^{2}$ the most common diseases pigeons include coccidiosis, trichomoniasis and respiratory infections, which are also confirmed in our study (Figure 1). Mixed infections with intestinal nematodes and coccidia were found in $42 \%$ of domestic pigeons and in $14.3 \%$ of the wild. As can be seen from the research, parasitic infection was greater in domestic pigeons than in the wild. ${ }^{16,17}$ In Istanbul (Turkey), in feral pigeons nesting in famous mosques, mixed infections of coccidia and nematodes were detected: Capillaria obsignata-19.3\% and Ascaridia columbae $-14.6 \% .{ }^{17}$ Moreover, mixed infections were described in other regions of Turkey: E. labbeana and $E$. columbarum were found in wild pigeons, which were infected in $15.1 \%$. The parasites affect the health of pigeons and are among the most common pathogens, which can reduce flight effectiveness. ${ }^{1,15}$

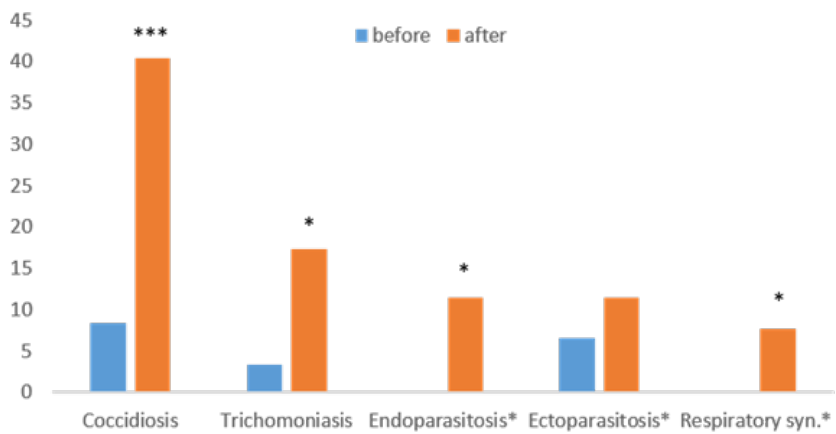

Figure I Comparison of the most common diseases of pigeons before and after race season.

Legend : Endoparasitosis* - caused by Ascaridia spp, Capillaria spp Ectoparasitosis*- caused by Columbicola columbae, Ceratophylus columbae, Respiratory syn* - respiratory syndrome determined according to clinical manifestations.

\section{Conclusion}

Our study showed that the young pigeon microflora is dominated and composed of mainly host specific bacteria by enterococci and streptococci during the race season. The commensal bacteria especially coagulase negative and positive staphylococci, that are part of the microflora, can also act as an opportune pathogen as a result a number of stress conditions, which leads to substantial exhaustion of birds and increases their susceptibility to various diseases.

\section{Acknowledgements}

None.

\section{Conflict of interest}

The author declares no conflict of interest.

\section{References}

1. Zigo F, Takáč L, Chripková M, et al. Infectious diseases of carrier pigeons and antimicrobial resistance in isolated bacteria. Int J of Sci Res. 2016;5(1):2277-8179.

2. Balicka RA, Pilarczyk B. Occurrence of coccidia infection in pigeons in amateur husbandry. Diagnosis and prevention. Ann Parasitol. 2014;60(2):93-97.

3. Karatepe M, Kılıç S, Karatepe B, et al. Parasites of domestic (Columba livia domestica) and wild (Columba livia livia) pigeons in Niğde, Turkey. Bul of the Vet Ins in Pulawy. 2008;52:551- 554.

4. Baele M, Devriese LA, Butaye P, et al. Composition of enterococcal and streptococcal flora from pigeon intestines. $J$ Appl Microbiol. 2002;92(2):348-351.

5. Kimpe A, Decostere A, Martel A, et al. Prevalence of antimicrobial resistance among pigeon isolates of Streptococcus gallolyticus, Escherichia coli and Salmonella enterica serotype Typhimurium. Avian Pathol. 2002;31(4):393-397.

6. Scullion FT, Scullion MG. Investigation of diseases in young racing pigeons. 1997:73-75.

7. Dranzoa C, Ocaido M, Katete P. The ecto, gastro-intestinal and haemo parasites of live pigeons (Columba livia) in Kampala, Uganda. Av Pat. 1999;28(2):119-124 
8. Stenzel T, Koncicki A. Occurrence of parasitic invasions in domestitc pigeons (Columba livia domestica) in the Northern Poland. Pol J of Vet Sci. 2007;10(4):275-278.

9. Facklam RR, Collins MD. Identification of Enterococcus species isolated from human infections by conventional test scheme. J Clin Microbiol. 1989;27(4):731-734

10. Aarestrup FM, Agerso Y, Gerner-Smidt $\mathrm{P}$, et al. Comparison of antimicrobial resistance phenotypes and resistance genes in Enterococcus faecalis and Enterococcus faecium from humans in the community, broilers, and pigs in Denmark. Diagn Microbiol Infect Dis. 2000;37(2):127-137.

11. Radimersky T, Frolkova P, Janoszowska D, et al. Antibiotic resistance in faecal bacteria (Escherichia coli, Enterococcus spp.) in feral pigeons. Jour of Appl Mic. 2010;109(5):1687-1695.

12. Devriese LA, Pot B, Kersters K, et al. Acidification of methyl-alfa-Dglucopyranoside:a useful test to differentiate Enterococcus casseliflavus and Enterococcus gallinarum from Enterococcus faecium species group and from Enterococcus faecalis. Jour Clin Microbiol. 1996;34:26072608 .
13. Devriese LA, Pot B, Collins MD. Phenotypic identification of the genus Enterococcus and differentiation of phylogenetically distinct enterococcal species and species groups. Jour Appl Bac. 1993;75(5):399-408.

14. Devriese LA, Pot B, Van Damme L, et al. Identification of Enterococcus species isolated from foods of animal origin. Int Jour Food Mic. 1995;26(2):187-197.

15. Hand O. The Effects of Stress on Racing Pigeons. 2004.

16. Merdivenci A. Istanbul camilerinde yuvalanan guvercin (Columba livia) lerde parazit insidensi. Turk Biyol Derg. 1963;13:81-86.

17. Koroglu E, Şimşek S. The prevalence of Eimeria species in pigeons (Columba livia) in Elazig. Fırat Universitesi Sağlık Bilimleri Dergisi. Vet. 2001;15:401-403. 